\title{
Detection and phylogenetic analysis of norovirus from individual septic tanks in the drainage basin of the coastal area located in the Jaran Bay of Korea
}

\author{
In Tae Ham', Byeo Ri Kim', Yu Jeong Park', Yeun Joong Jung ${ }^{1}$, Kunbawui Park' , Ji Young Kwon², \\ Jong Soo Mok ${ }^{1}$, Hongsik Yu ${ }^{1, *}$ \\ ${ }^{1}$ Food Safety and Processing Division, National Institute of Fisheries Science, Busan 46083, Korea \\ ${ }^{2}$ Southeast Sea Fisheries Institute, National Institute of Fisheries Science, Tongyeong 53085, Korea
}

\begin{abstract}
Norovirus (NoV) prevalence was investigated in 100 sewage samples collected from 35 individual septic tanks around the drainage basin of Jaran Bay, Korea in January, May, and July of 2017. Genotypes and diversity of NoV strains detected in sewage samples were also assessed using the conventional RT-PCR and phylogenetic analysis. NoV Gl or Gll were detected in 22 (22.0\%) and 24 (24.0\%) samples, respectively. Thirteen genotypes were identified with three dominant genotypes (GI.9, GII.5 and GII.17) and Gll.17 showed relatively higher prevalence during the survey period. Gll.17 strains were clustered into recombinant type variant or NoV Gll.17 Kawasaki variant. NoV Gll.17 strains were considered emergent epidemic variants with widespread circulation. NoV surveillance strategy should include both environmental (sewage) and clinical data to reveal minor NoV genotypes likely cause of asymptomatic or underreported infections in the local population.
\end{abstract}

Keywords: Norovirus, Septic tank, Sewage, NoV Gll.17, Shellfish production area

\section{Introduction}

Of more than 140 enteric viruses identified from human faces, NoV has been the leading causative pathogen of acute viral gastroenteritis (Leclerc, et al., 2000). NoV is positive-sense single stranded RNA virus classified into family Caliciviridae and comprise six genogroups (Trujillo et al., 2006). GI and GII groups are more commonly associated with human illness (Zheng et al., 2006) and each group is currently subdivided into
9 and 22 genotypes, respectively (Lu et al., 2015). NoV transmission pathways are the fecal-oral route by consumption of uncooked contaminated food as well as by contact of the person, aerosol and the solid surface (Cho et al., 2011).

$\mathrm{NoV}$ is the common cause of gastrointestinal illness all over the world (de Wit MA et al., 2001; Patel et al., 2008; Scallan et al., 2011). Many countries reported abundant cases of NoV infection with very significant economic costs on a regular basis. In the United States, NoV is estimated to cause 21 million

Received: Oct 30, 2020 Revised: Dec 8, 2020 Accepted: Dec 14, 2020

${ }^{\star}$ Corresponding author: Hongsik Yu

Food Safety and Processing Division, National Institute of Fisheries Science, Busan 46083, Korea

Tel: +82-51-720-2630, Fax: +82-51-720-2619, E-mail: yhspknu@korea.kr, ORCID: https://orcid.org/0000-0001-9520-2016

This is an Open Access article distributed under the terms of the Creative Commons Attribution Non-Commercial License (http://creativecommons.org/licenses/by$\mathrm{nc} / 4.0 /$ ) which permits unrestricted non-commercial use, distribution, and reproduction in any medium, provided the original work is properly cited.

Copyright $\odot 2021$ The Korean Society of Fisheries and Aquatic Science 
cases (Scallan et al., 2011) and \$184 million of the cost of illness annually (Batz et al., 2011). In Korea, NoV infection was first officially reported in 1999. In 2006, the outbreak occurred in which 2,400 students were infected through consumption of contaminated food via groundwater at the food service centers of 31 schools, which aroused social concern about the NoV infectious disease (Lee et al., 2013).

There have been many cases of NoV infection associated with the consumption of contaminated shellfish (Koo et al., 2016; Prato et al., 2004; Smith et al., 2009; Webby et al., 2007; Westrell et al., 2010). Historically, the monitoring of regular fecal indicator bacteria in the shellfish production areas is the most common strategy to secure the safety of shellfish (Oh et al., 2015). However, evidences have demonstrated that NoV persists for longer periods than fecal indicator bacteria in actively filtering shellfish (Oh et al., 2015; Schwab et al., 1998). Major $\mathrm{NoV}$ contamination sources in shellfish production areas have been the discharges of untreated sewage from small individual septic tanks (Borchardt et al., 2011; Rodriguez et al., 2012).

Direct discharges into production areas have clearly shown the links between $\mathrm{NoV}$ in sewage and gastrointestinal illness (Nenonen et al., 2008; Ueki et al., 2005; Wall et al., 2011). In other words, raw sewage may act as a valuable source to characterize the prevalence of enteric viruses in a human population. Accordingly, several studies have used raw sewage for molecular epidemiology as a source of information on the viruses circulation through the fecal-oral route (Fumian et al., 2019; La Rosa et al., 2017; Montazeri et al., 2015; Nenonen et al., 2008; Prado et al., 2018).

In this study, we examined the prevalence of $\mathrm{NoV}$ in sewage samples from the drainage basin of Jaran Bay, Korea. We assessed genotypes and diversity of $\mathrm{NoV}$ strains detected in sewage samples collected from individual septic tanks in January, May and July of 2017.

\section{Materials and Methods}

\section{Sampling site}

Sampling was conducted at 7 villages along the coastline of Jaran Bay facing Goseong County and Tongyeong, South Korea (Fig. 1). In each village, five septic tanks located closest to the coast were selected for sampling. Jaran Bay is surrounded by the coastline of Samsan-myeon and Hail-myeon of Goseong County and the southern part is open to the Pacific Ocean. About 800 shellfish farming licenses were issued in about $76 \mathrm{~km}^{2}$ coastal area.

\section{Preparation of viral concentrates}

In January, May, and July of 2017, 1 L of sewage was collected from each septic tank and transported to the laboratory at below $4^{\circ} \mathrm{C}$ and NoV genotype distribution was investigated among a total of 100 sewage samples. On the sampling day, 45 $\mathrm{mL}$ of sewage sample was centrifuged $\left(170,000 \times \mathrm{g}, 60 \mathrm{~min}, 4^{\circ} \mathrm{C}\right)$ using the ultracentrifuger (Beckman Coulter, Brea, CA, USA). The pellet was resuspended in $5 \mathrm{~mL}$ of glycine buffer $(0.75 \mathrm{M}$ glycine/0.15 M NaCl, pH 7.6) (Sigma-Aldrich, St. Louis, MO, USA) then $50 \mathrm{~mL}$ of $2 \times$ PBS (Merck, Darmstadt, Germany) as added. The solution was stirred for $20 \mathrm{~min}$ on ice and then centrifuged $\left(12,000 \times \mathrm{g}, 20 \mathrm{~min}, 4^{\circ} \mathrm{C}\right)$. The supernatant was adjusted to $45 \mathrm{~mL}$ using $1 \times \mathrm{PBS}$ and then flocs were sedimented by centrifugation $\left(170,000 \times \mathrm{g}, 60 \mathrm{~min}, 4^{\circ} \mathrm{C}\right)$. The pellet was resuspended in $1 \mathrm{~mL}$ of $1 \mathrm{x}$ PBS and stored at $-80^{\circ} \mathrm{C}$ for downstream analysis.

\section{RNA extraction, RT-PCR and sequencing}

Viral RNA was extracted from $500 \mu \mathrm{L}$ of viral suspension using $\mathrm{eMAG}^{\mathrm{m}}$ instruments (bioMerieux, Grenoble, France) according to the procedure of the eMAG-specific program (IND_B20t_ On_Ves_SB_1). For detection of NoV from stool samples, RT semi-nested PCR was performed using a previously described primer sets (Table 1) (Cheon et al., 2010). Extracted RNA was firstly amplified using Verso 1-Step RT-PCR Kit ReddyMix (Thermo Fisher Scientific, Waltham, MA, USA) under the following conditions: a reverse transcription step at $45^{\circ} \mathrm{C}$ for $30 \mathrm{~min}$ and PCR involving an initial activation step at $94^{\circ} \mathrm{C}$ for $5 \mathrm{~min}$, followed by $35 \mathrm{cycles}$ each of $94^{\circ} \mathrm{C}$ for $30 \mathrm{sec}, 55^{\circ} \mathrm{C}$ for $30 \mathrm{sec}$, and $72^{\circ} \mathrm{C}$ for $1 \mathrm{~min} 30 \mathrm{sec}$, with a final extension step at $72^{\circ} \mathrm{C}$ for $7 \mathrm{~min}$. A semi-nested PCR amplification procedure was then performed using Top DNA Polymerase (Bioneer, Daejeon, Korea) as follows: $94^{\circ} \mathrm{C}$ for $5 \mathrm{~min}$, followed by 25 cycles of $94^{\circ} \mathrm{C}$ for $30 \mathrm{sec}, 55^{\circ} \mathrm{C}$ for $30 \mathrm{sec}$, and $72^{\circ} \mathrm{C}$ for $90 \mathrm{sec}$, followed by a final extension step at $72^{\circ} \mathrm{C}$ for $7 \mathrm{~min}$. The amplified fragments were purified using the Wizard ${ }^{\oplus}$ SV Gel and PCR CleanUp System (Promega, Madison, WI, USA) and then cloned using the TOPcloner ${ }^{\mathrm{TM}}$ TA core Kit (Enzynomics, Daejeon, Korea) according to manufacturer's instruction. Plasmid DNA was purified using the AccuPrep ${ }^{\bullet}$ Plasmid Mini Extraction Kit (Bioneer), and DNA was sequenced by the Cosmogentech, Ltd., South Korea.

\section{Phylogenetic analysis}

The analyzed nucleoprotein $(\mathrm{N})$ site sequence of the isolated 


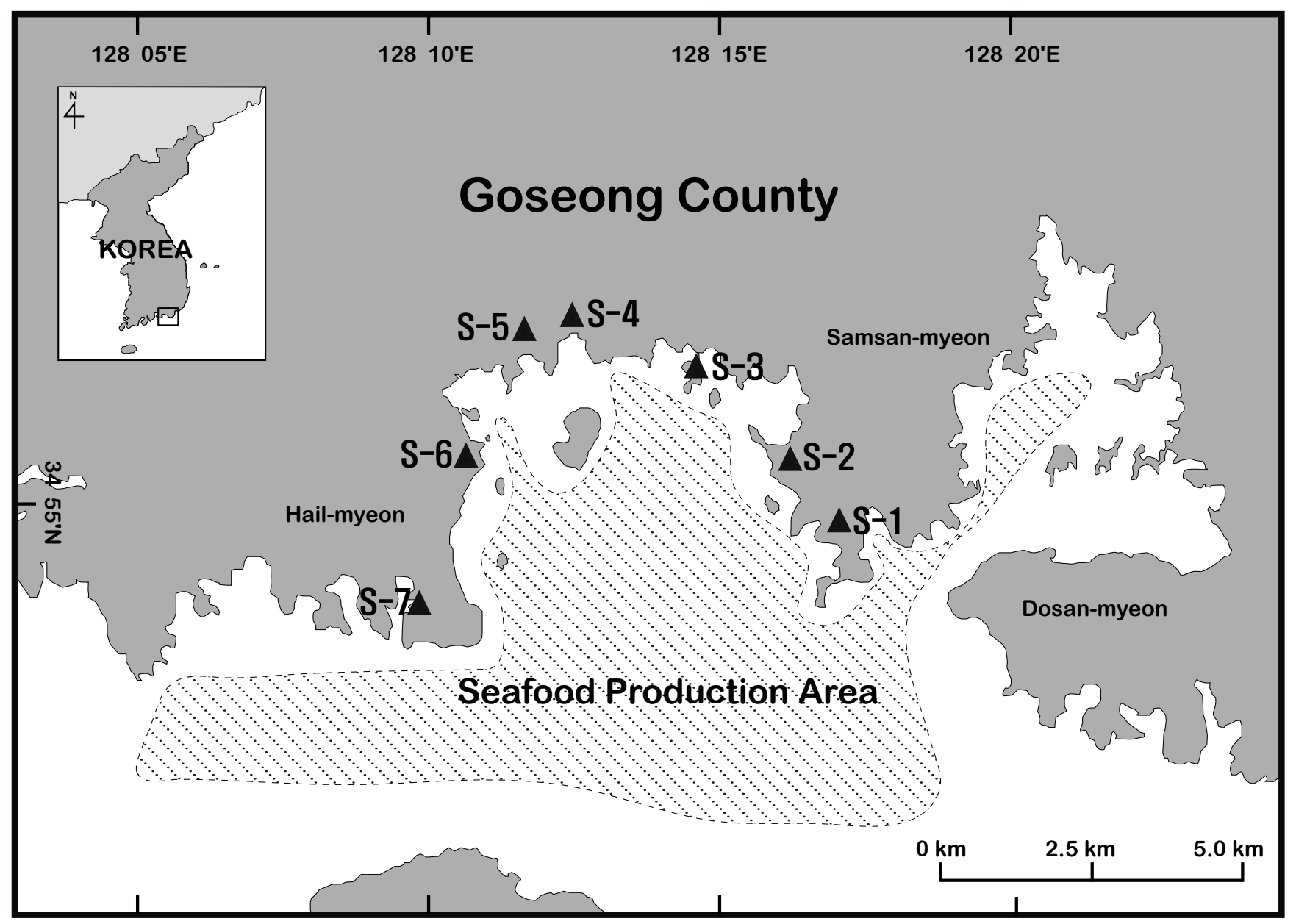

Fig. 1. Location of the sampling sites in Jaran Bay, South Korea. The filled triangle indicates the sampling site.

Table 1. Primers used for nested RT-PCR

\begin{tabular}{llll}
\hline Genogroup & Primers (Polarity) & Sequence(5'-3') & Position $^{2)}$ \\
\hline I & GI-F1M (Sense) & CTG CCC GAATTY GTA AAT GAT GAT & $5341-5364$ \\
& GI-F2 (Sense) & ATG ATG ATG GCG TCT AAG GAC & $5357-5379$ \\
& GI-R1M (Antisense) & CCA ACC CAR CCA TTR TAC ATY & $5648-5670$ \\
\hline II & GII-F1M (Sense) & GGG AGG GCG ATC GCA ATCT & $5048-5063$ \\
& GII-F3M (Sense) & TTG TGA ATG AAG ATG GCG TCG & $5078-5101$ \\
& GII-R1M (Antisense) & CCR CCI GCA TRI CCR TTR TAC AT & $5366-5388$ \\
\hline
\end{tabular}

${ }^{1)}$ Degenerate position $\mathrm{Y}: \mathrm{C} / \mathrm{T}, \mathrm{R}: \mathrm{A} / \mathrm{G}$, I:Inosine.

2) Primer positions of NoV GI based on GeneBank ID JX023285 and NoV GIl based on GeneBank ID JQ622197.

strain was identified using BLAST (http://blast.ncbi.nlm.nih. gov/ Blast.cgi) and the genotype showing the highest homology through comparative analysis with the existing NoV standard strain sequence registered in GenBank (http://www.ncbi.nlm. nih.gov). Sequences were aligned using the ClustalW program, and genetic distances and phylogenetic trees between base sequences were inferred by the neighbor-joining method using the MEGA-X v 10.1.8 (Molecular Evolutionary Genetics Analysis version 10.1.8) program. Also, the bootstrap value was deduced from 1,000 resampled data. 


\section{Results}

\section{Norovirus genotype and distribution}

In January, May and July of 2017, a total of 100 raw sewage samples were collected from 35 septic tanks in 7 villages. In total, NoV GI or GII were detected in 22 (22.0\%) and 24 (24.0\%) samples, respectively. Ten samples contained both NoV GI and NoV GII (Table 2). The 22 GI-positive samples were genotyped as GI.1, GI.3, GI.4, GI.5, GI.6 and GI.9 and 24 GII positive samples were GII.1, GII.2, GII.3, GII.4, GII.5, GII.6 and GII.17. The genotypic distribution of the $13 \mathrm{NoV}$ strains was as follows: GI.1 (5.5\%, n=3); GI.3 (9.1\%, n=5); GI.4 (1.8\%, n=1); GI.5 (9.1\%, $\mathrm{n}=5)$; GI.6 (7.3\%, n=4); GI.9 (12.7\%, n=7); GII.1 (3.6\%, n=2); GII.2 (9.1\%, n=5); GII.3 (3.6\%, n=2); GII.4 (5.5\%, n=3); GII.5 (12.7\%, n=7); GII.6 (3.6\%, n=2); GII.17 (16.4\%, n=9) (Table 2). Among identified thirteen NoV genotypes, three genotypes
(GI.9, GII.5 and GII.17) were dominant (Fig. 2A). NoV GII.17 showed relatively higher prevalence during the survey period. NoVs were detected in raw sewage samples collected at 23 out of 35 septic tanks in January (the winter of Korea), recording an exceptionally high overall detection rate of $65.7 \%$. All thirteen genotypes were identified in January while three and four genotypes were identified in May and July, respectively (Fig. 2B).

\section{Phylogenetic analysis of NoV GII.17}

By phylogenetic analysis, the genetic diversity of NoV GII.17 strains detected with those of reference strains was evaluated using their partial capsid sequence. In the phylogenetic tree, 7 strains were clustered into two sub-clusters (Fig. 3). Five strains isolated clustered with recombinant type variant newly emerged in 2017 in South Korea (Cluster A) and 2 strains were clustered into the recently emerged NoV GII.17 Kawasaki variant (Cluster B).

Table 2. Genogroup and genotype of norovirus genomes in raw sewage

\begin{tabular}{|c|c|c|c|c|c|c|}
\hline \multirow[t]{2}{*}{ Station } & \multicolumn{6}{|c|}{ Genotypes (GenBank Accession No.) } \\
\hline & January & & May & & July & \\
\hline $\mathrm{DH}-1$ & Gl.1 & (KP753266.1) & & & & \\
\hline $\mathrm{DH}-2$ & & & & & Gll.5/GIl.17 & (KT383997.1)/(MN461128.1) \\
\hline $\mathrm{DH}-4$ & Gll.5 /Gll.17 & (EU249129.1)/(MN461047.1) & & & Gll.5 & $(\mathrm{KX764772.1)}$ \\
\hline DS-1 & Gl.9 & (MN494362.1) & Gll.5 & (KT383997.1) & $\mathrm{Gl} .5$ & (MN525237.1) \\
\hline DS-3 & Gll.17 & (MN461128.1) & & & & \\
\hline DS-4 & Gl.1 & (KP753266.1) & & & & \\
\hline DS-5 & Gl.5 & (MN494561.1) & & & & \\
\hline SC-2 & GI.3/GII.1/GIl.6 & (MN922717.1)/(MN461066.1)/(MN461133.1) & & & Gll.17 & $(K X 764701.1)$ \\
\hline SC-3 & GI.3/GII.1/GIl.6 & (MN494192.1)/(KX764814.1)/(KT384016.1) & & & & \\
\hline SC-4 & GI.5/Gll.5 & (KT383954.1)/(KX764772.1) & & & & \\
\hline DP-2 & Gll.2 & (MN461154.1) & & & & \\
\hline DP-5 & Gll.5/Gll.17 & $(K X 764820.15) /(K X 764704.1)$ & & & GIl.5/GIl.17 & $($ KX764748.1)/(KT384043.1) \\
\hline YT-2 & Gl.4/GIl.2/GIl.4 & (KR107857.1)/(MH806426.1)/(MN461099.1) & & & & \\
\hline YT-3 & Gll.17 & (MN461059.1) & & & & \\
\hline YT-4 & Gl.9/GIl.3 & (MN494475.1)/(MN461098.1) & & & & \\
\hline YT-5 & Gl.9/GIl.3 & (MN494242.1)/(MN494620.1) & & & & \\
\hline ST-1 & Gl.3/GII.17 & (MN922717.1)/(MN461128.1) & & & & \\
\hline ST-2 & Gll.2 & (MN461154.1) & & & & \\
\hline ST-3 & Gl.9 & (MN494475.1) & & & & \\
\hline ST-4 & $\mathrm{Gl} .1$ & (KP753266.1) & & & & \\
\hline ST-5 & Gl.3/GI.9/Gll.2 & (MN494274.1)/(MN494235.1)/(MH825867.1) & & & & \\
\hline SS-1 & & & $\mathrm{Gl} .6$ & $(\mathrm{KX} 245214.1)$ & Gl.6 & $(K X 245214.1)$ \\
\hline SS-2 & GI.6/GIl.17 & $(\mathrm{KX} 245225.1) /(\mathrm{KX764746.1)}$ & & & & \\
\hline SS-3 & Gl.5/GI.9/Gll.2 & (MN494561.1)/(MN421757.1)/(MN461154.1) & Gll.4 & $(K X 764852.1)$ & $\mathrm{Gl} .5$ & (MN494541.1) \\
\hline SS-4 & Gl.3/Gl.6 & (MN421644.1)/(MN421637.1) & & & & \\
\hline
\end{tabular}


(A)

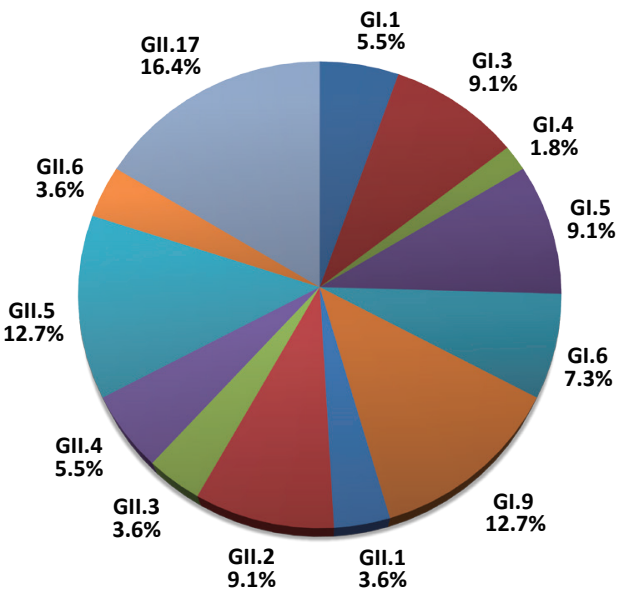

(B)

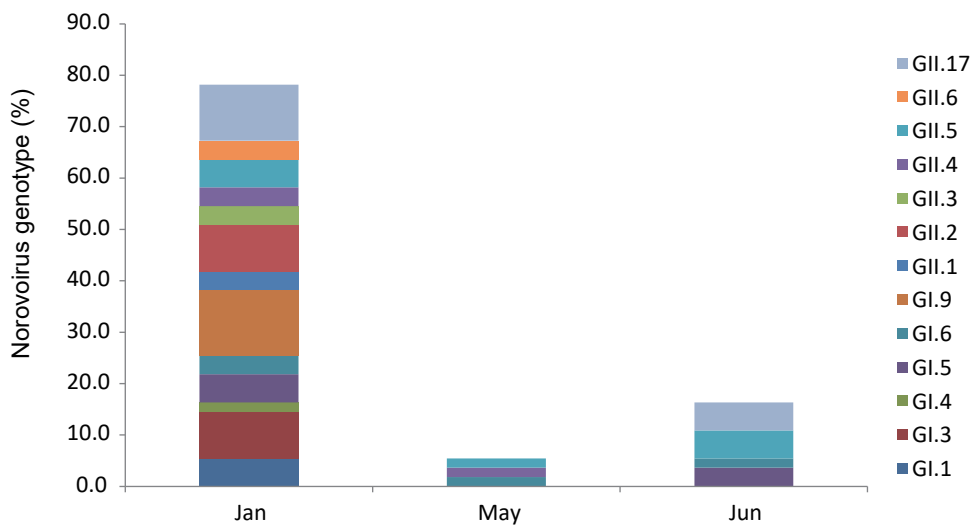

Fig. 2. Norovirus genotype distribution in raw sewage samples. (A) Total distribution of norovirus identified from raw sewage samples during the study period, (B) Distribution of norovirus genotype each sampling month. The $\mathrm{X}$ and $\mathrm{Y}$-axis represent the norovirus sampling time and the norovirus distribution in percentage.

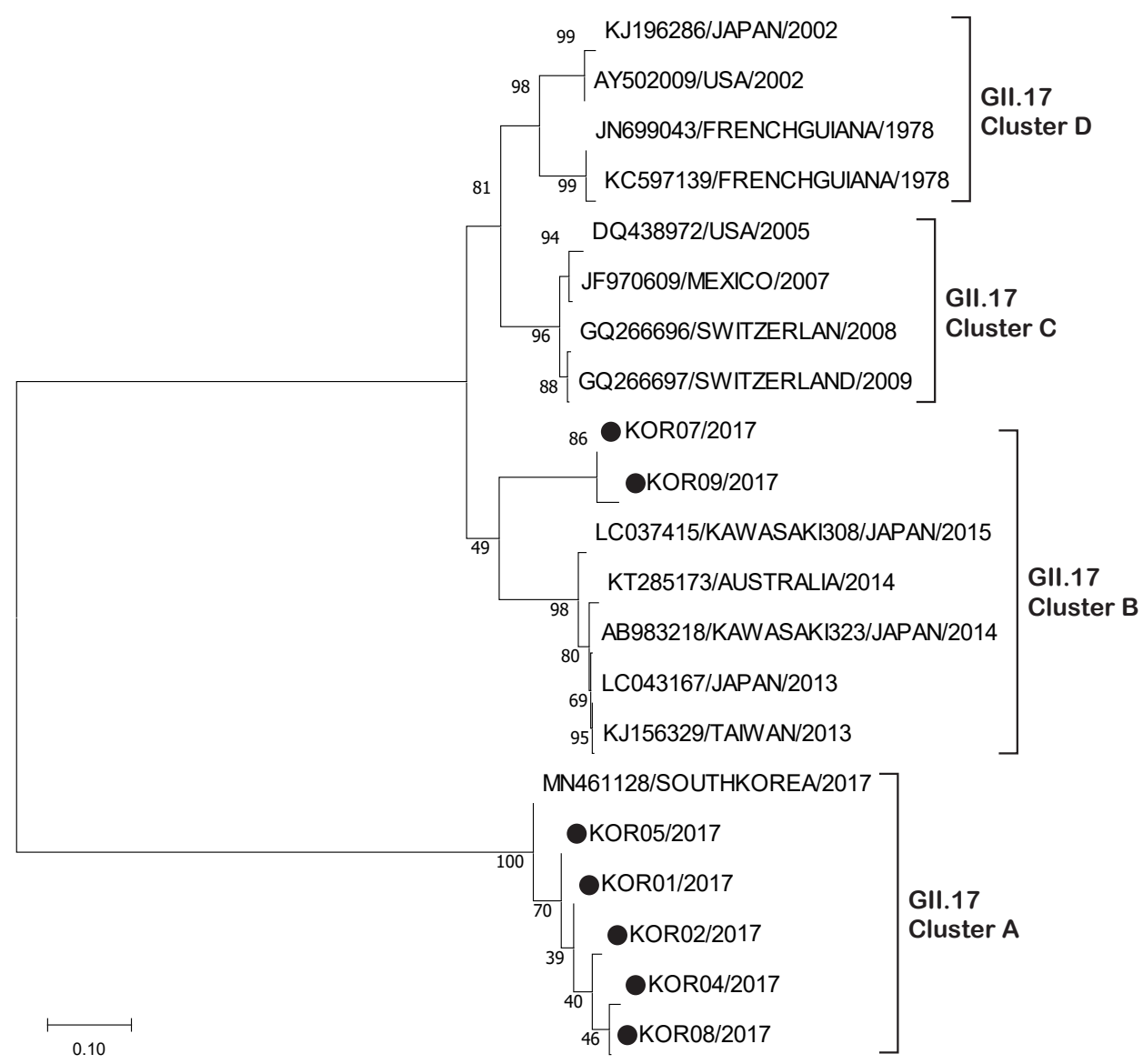

Fig. 3. Phylogenetic tree based on capsid region of GII.17 norovirus. Strains obtained in this study are marked with black filled circles. Reference strains were downloaded from GenBank and labelled with their accession number followed by genotype, country and year. 


\section{Discussion}

Although the investigation period was short, NoV detection rate and genotype diversity in this study showed remarkable seasonality. Ahmed et al. (2013) conducted a systematic review of report on monthly counts of NoV between 1997 and 2011 and analyzed seasonal patterns of NoV disease. The research identified that $41.2 \%$ of outbreaks and $52.7 \%$ of cases occurred in cold months. Koo et al. (2016) investigated molecular epidemiology of NoV infections from outbreaks in Busan, Korea from 2012 to 2015 and it was found that NoVs were most frequently detected in November (25.4\%) and February (28.2\%). A meta-analysis of $\mathrm{NoV}$ identified in raw sewage from various temperate climate countries showed a high degree of a winter peak for both GI and GII genogroups (Eftim et al., 2017). Our findings are broadly consistent with the NoV concept of a winter virus, at least in temperate climate. However, there is no opportunity to access sufficient reports of $\mathrm{NoV}$ outbreaks in Africa, South America, and tropical regions, so it is insufficient to assert the seasonality of NoV incidences and relevant acute gastroenteritis outbreaks.

Among identified thirteen NoV genotypes, NoV GII.17 showed relatively higher prevalence during the survey period. NoV GII.17 is an uncommon genotype which recently emerged in China and spread throughout other south-east Asian countries resulting in an increased number of acute gastroenteritis outbreaks reported within this region (Lu et al., 2015; Matsushima et al., 2015). The GII.17 Kawasaki 2014 has also been detected in many countries in North and South America, Europe and Oceania (Andrade et al., 2017; Lun et al., 2018; Medici et al., 2014; Oh et al., 2015; Parra \& Green, 2015). The molecular epidemiology of acute gastroenteritis outbreaks, which have been mainly caused by NoV GII.4 variants since the mid-1990s, are changing globally with the emergence of NoV GII.17. Nam et al. (2014) reported that 35 acute gastroenteritis outbreaks occurred in Gyeonggi Province of South Korea in early 2015 were caused by NoV GII.17 Kawasaki 2014. Above findings encourage some authors to suggest GII.17 might replace GII.4 as the predominant $\mathrm{NoV}$ strain around world at some point (Bruggink et al., 2016).

In Brazil, it was presumed that GII.17 Kawasaki variant was introduced in 2014 during the 2014 FIFA World Cup event (Andrade et al., 2017). However, the molecular analysis of NoVs detected in raw sewage showed that this variant has already been circulating since mid-2013 in Brazil (Fumian et al., 2019).
This could be related to asymptomatic or mild infections of this genotype that do not lead to hospital visits. So, the unmatched results may be a reflection of underestimation over circulation of NoV GII.17. Sewage analysis is an important molecular surveillance tool to understand the genetic diversity of enteric viruses in a human population (La Rosa et al., 2017; Mabasa et al., 2015; Montazeri et al., 2015; Prado et al., 2018). WHO used sewage to monitor poliovirus circulation in communities worldwide as a part of the Global Polio Eradication Initiative with combining clinical surveillance (Benschop et al., 2005).

If human enteric viruses including NoVs and hepatitis A virus are presenting in the stools originated relevant patients, surface water and sea water may be polluted with these viruses (Lodder et al., 2005; Metcalf et al., 1982). Shellfish accumulates NoV from surrounding water during filter-feeding in their digestive glands and other tissues within 4 to $24 \mathrm{~h}$ (Wang et al., 2008; Asahina et al., 2009), which may cause the gastrointestinal disease. Monitoring on oyster production areas in the United Kingdom, France and Ireland, NoV (GI plus GII) ranging from $10^{2}$ genome copies/g to $10^{4}$ genome copies/g was detected (Wyn-Jones \& Sellwood, 2001). Monitoring on farmed and wild mussels, clams, and cockles detected NoV ranging from $10^{1}$ to $10^{4}$ copies/g in Galicia, Spain (Vilariño et al., 2009). Although various shellfish are almost consumed after heating and boiling but the heat treatment at the level of shells opening is insufficient to inactivate viruses (Myrmel et al., 2004).

Effective sewage treatment process is essential to prevent environmental contamination before the discharge of effluents into water bodies used by the public thus mitigating the risk of viral transmission to the population. However NoV is removed to only a limited extent by sewage treatment processes and, consequently, the virus is commonly detected in final discharges of waste water treatment plants under normal operational status (Carlos \& Lees, 2014). The secondary strategy for the risk reduction is therefore to secure the prohibited zone (i.e. buffer zone) for sufficient dilution and dispersion of viral particles between the final discharge points of waste water treatment plants and the impacted seafood production areas.

In conclusion, we successfully identified the circulation of three major prevalent genotypes (GI.9, GII.5 and GII.17) in raw sewage samples during the study period. Among those, $\mathrm{NoV}$ GII.17 strains were considered emergent epidemic variants with widespread circulation. NoV showed a genetic diversity in raw sewage with thirteen major and minor genotypes. NoV surveillance strategy should include both environmental (sewage) and 
clinical data to reveal minor NoV genotypes likely cause asymptomatic or underreported infections in the local population. The strategy for mitigation of viral infection risk is the effective sewage treatment and sufficient dilution of final effluents before reaching to the seafood production areas.

\section{Competing interests}

No potential conflict of interest relevant to this article was reported.

\section{Funding sources}

This work was supported by a grant from the National Institute of Fisheries Science in Korea (R2020052).

\section{Acknowledgements}

Not applicable.

\section{Availability of data and material}

Upon reasonable request, the datasets of this study can be available from the corresponding author.

\section{Ethics approval and consent to participate}

This article does not require IRB/IACUC approval because there are no human and animal participants.

\section{References}

Ahmed SM, Benjamin L and Karen L. A systematic review and meta-analysis of the global seasonality of norovirus. PLOS ONE. 2013;8:e75922.

Andrade JSR, Fumian TM, Leite JPG, Assis MR, Bello G, Mir D, et al. Detection and molecular characterization of emergent GII.P17/GII.17 Norovirus in Brazil, 2015. Infect Genet Evol. 2017;51:28-32.

Asahina AY, Lu Y, Wu C, Yao L, Zhang J. Potential biosentinels of human waste in marine coastal waters: bioaccumulation of human noroviruses and enteroviruses from sewage-polluted waters by indigenous mollusks. J Virol Methods. 2009;158:46-50.

Batz MB, Hoffmann S, Morris JG Jr. Ranking the risks: the 10 pathogen-food combinations with the greatest burden on public health. Gainesville, FL: Emerging Pathogens Institute, University of Florida; 2011.

Benschop KSM, van der Avoort HG, Jusic E, Vennema H, van Binnendijk R, Duizer E. Polio and measles down the drain: environmental enterovirus surveillance in the Netherlands, 2005 to 2015. Appl Environ Microbiol. 2017;83:e00558-17.

Borchardt MA, Bradbury KR, Alexander EC Jr, Kolberg RJ, Alexander SC, Archer JR, et al. Norovirus outbreak caused by a new septic system in a dolomite aquifer. Ground Water 2011;49:85-97.

Bruggink LD, Triantafilio MJ and Marshall JA. The molecular epidemiology of norovirus outbreaks in Victoria, 2016. Commum Dis Intell. 2018;42:1-11.

Carlos JA, Lees DN. Environmental transmission of human noroviruses in shellfish waters. Appl Environ Microbiol. 2014;80:3552-61.

Cheon DS, Jeong HS, Jeong A, Lee KB, Lee MH, Tahk H, et al. Seasonal prevalence of asymptomatic norovirus infection in Korean children. Foodborne Pathog Dis 2010;7:1427-30.

Cho MG, Jeong HM, Ahn JB, Kim KY. Detection of feline calicivirus as norovirus surrogate in food and water sources using filtration and real-time RT-PCR. Food Sci Biotechnol. 2011;20:1475-80.

de Wit MA, Koopmans MP, Kortbeek LM, Wannet WJ, Vinje J, Leusden AI, et al. Sensor, a population-based cohort study on gastroenteritis in the Netherlands: incidence and etiology. Am J Epidemiol. 2001;154: 666-74.

Eftim E, Hong T, Soller J, Boehm A, Warren I, Ichida A, et al. Occurrence of norovirus in raw sewage - a systematic literature review and metaanalysis. Water Res. 2017;111:366-74.

Fumian TM, Fioretti JM, Lun JH, dos Santos IAL, White PA, Miagostovichb MP. Detection of norovirus epidemic genotypes in raw sewage using next generation sequencing. Environ Int. 2019;123:282-91.

Koo HS, Pyeong TK, Lee MO, Baik HS. Prevalence of noroviruses detected from outbreaks of acute gastroenteritis in Busan, Korea. J Life Sci. 2016;26:911-20.

La Rosa G, Della S, Iaconelli M, Proroga R, De Medici D, Martella V, et al. Detection of norovirus GII.17 Kawasaki 2014 in shellfish, marine water and underwater sewage discharges in Italy. Food Environ Virol. 2017;9:326-33.

Leclerc H, Edberg S, Pierzo V, Delattre JM. Bacteriophages as indicators of enteric viruses and public health risk in groundwaters. J Appl Microbiol. 2000;88:5-21.

Lee MH, Seo DT, Seo J, Wang X, Lee JS, Joo IS, et al. Trends and epidemiology of norovirus outbreaks. J Food Hyg Saf. 2013;8:3-11.

Lodder WJ, de Roda Husman AM. 2005. Presence of noroviruses and other enteric viruses in sewage and surface waters in 
the Netherlands. Appl Environ Microbiol. 71:1453-61.

Lu J, Sun L, Fang L, Yang F, Mo Y, Lao J, et al. Gastroenteritis outbreaks caused by norovirus GII.17, Guangdong province, China, 2014-2015. Emerg Infect Dis 2015;21:1240-2.

Lun JH, Hewitt, J, Sitabkhan A, Eden JS, Enosi Tuipulotu D, Netzle NE, Morrell L, et al. Emerging recombinant noroviruses identified by clinical and waste water screening. Emerg Microbes Infect. 2018;7:50.

Mabasa VV, Meno KD, Taylor MB, Mans J. Environmental surveillance for noroviruses in selected south African wastewaters 2015-2016: emergence of the novel GII.17. Food Environ Virol. 2018;10:16-28.

Matsushima Y, Ishikawa M, Shimizu T, Komane A, Kasuo S, Shinohara M, et al. Genetic analyses of GII.17 norovirus strains in diarrheal disease outbreaks from December 2014 to March 2015 in Japan reveal a novel polymerase sequence and amino acid substitutions in the capsid region. Euro Surveill. 2015;20:21173.

Medici MC, Tummolo F, Calderaro A, Chironna M, Giammanco GM, De Grazia S, et al. Identification of the novel Kawasaki 2014 GII.17 human norovirus strain in Italy, 2015. Euro Surveill. 2015;20:30010.

Metcalf TG. Virus in shellfish-growing waters. Environ Int. 1982;7:21-7.

Montazeri N, Goettert D, Achberger EC, Johnson CN, Prinyawiwatkul W, Janes ME. Pathogenic enteric viruses and microbial indicators during secondary treatment of municipal wastewater. Appl Environ Microbiol. 2015;81:6436-45.

Myrmel M, Berg EM, Rimstad E, Grinde B. Detection of enteric viruses in shellfish from the Norwegian coast. Appl Environ Microbiol. 2004;70:2678-84.

Nam SJ, Park PH, Bang SJ, Huh JW, Yun HJ, Park KH, et al. Molecular epidemiological study of norovirus gastroenteritis outbreaks in Gyeonggi-Do from 2014 to 2015. Korean J Microbiol. 2018; 54:24-30.

Nenonen NP, Hannoun C, Horal P, Hernroth B, Bergström T. Tracing of norovirus outbreak strains in mussels collected near sewage effluents. Appl Environ Microbiol. 2008;74:2544-9.

Oh EG, Song KC, Kim S, Park K, Yu H. Negative correlation between the prevalence of norovirus and high bacterial loads of Escherichia coli in oysters Crassostrea gigas. Fish Aquat Sci. 2015;18:235-40.

Parra GI, Green KY. Genome of emerging norovirus GII.17, United States, 2014. Emerg Infect Dis. 2015;21:1477-9.
Patel MM, Widdowson MA, Glass RI, Akazawa K, Vinje J, Parashar UD. Systematic literature review of role of noroviruses in sporadic gastroenteritis. Emerg Infect Dis. 2008; 14: 1224-31.

Prado T, de Castro A, Barbosa MRF, Garcia SC, Moreno LZ, Sato MIZ. Noroviruses in raw sewage, secondary effluents and reclaimed water produced by sand-anthracite filters and membrane bioreactor/reverse osmosis system. Sci Total Environ. 2018;646:427-37.

Prato R, Lopalco PL, Chironna M, Barbuti G, Germinario C, Quarto M. Norovirus gastroenteritis general outbreak associated with raw shellfish consumption in South Italy. BMC Infect Dis. 2004;4:37.

Rodriguez RA, Gundy PM, Rijal GK, Gerba CP. The impact of combined sewage overflows on the viral contamination of receiving waters. Food Environ Virol. 2012;4:34-40.

Scallan E, Hoekstra RM, Angulo FJ, Tauxe RV, Widdowson MA, Roy SL, et al. Foodborne illness acquired in the United States-major pathogens. Emerg Infect Dis. 2011;17: 7-15.

Schwab KJ, Neill FH, Estes MK, Metcalf TG, Atmar RL. Distribution of Norwalk virus within shellfish following bioaccumulation and subsequent depuration by detection using RT-PCR. J Food Prot. 1998;61:1674-80.

Smith AJ, McCarthy N, Saldana L, Ihekweazu C, McPhedran K, Adak GK, et al. A large foodborne outbreak of norovirus in diners at a restaurant in England between January and February 2009. Epidemiol Infect. 2012;140:1695-701.

Trujillo AA, McCaustland KA, Zheng DP, Hadle LA, Vaughn G, Adams SM, et al. Use of TaqMan real-time reverse transcription-PCR for rapid detection, quantification, and typing of norovirus. J Clin Microbiol. 2006;44:1405-12.

Ueki Y, Sano D, Watanabe T, Akiyama K, Omura T. Norovirus pathway in water environment estimated by genetic analysis of strains from patients of gastroenteritis, sewage, treated wastewater, river water and oysters. Water Res. 2005;39:4271-80.

Vilariño ML, Le Guyader FS, Polo D, Schaeffer J, Kröl J, Romalde JL. Assessment of human enteric viruses in cultured and wild bivalve molluscs. Int Microbiol. 2009;12:145-51.

Wall R, Dymond N, Bell A, Thornley C, Buik H, Cumming D, et al. Two New Zealand outbreaks of norovirus gastroenteritis linked to commercially farmed oysters. N Z Med J. 2011;124:63-71.

Wang D, Wu Q, Kou X, Yao L, Zhang J. Distribution of norovirus in oyster tissues. J Appl Microbiol. 2008;105:1966-72. 
Webby RJ, Carville KS, Kirk MD, Greening G, Ratcliff RM, Crerar SK, et al. Internationally distributed frozen oyster meat causing multiple outbreaks of norovirus infection in Australia. Clin Infect Dis. 2007;44:1026-31.

Westrell T, Dusch V, Ethelberg S, Harris J, Hjertqvist M, Jourdan-da Silva N, et al. Norovirus outbreaks linked to oyster consumption in the United Kingdom, Norway, France, Sweden and Denmark, 2010. Euro Surveill. 2010;15:19524

Wyn-Jones AP, Sellwood J. Enteric viruses in the aquatic environment. J Appl Microbiol. 2001; 91:945-62.

Zheng DP, Ando T, Fankhauser RL, Beard RS, Glass RI, Monroe SS. Norovirus classification and proposed strain nomenclature. Virology. 2006;346:312-23. 